\title{
Implementasi Data Mining Penjualan Produk Pakaian Dengan Algoritma Apriori
}

Sanjani ${ }^{1 *}$, Hasanul Fahmi2, Anita Sindar ${ }^{3}$

1,2,3Teknik Informatika STMIK Pelita Nusantara

Email: sanjanisanjani95@gmail.com ${ }^{1 *}$,h.fahmizuhri@gmail.com², haito_ita@yahoo.com³

\section{Info Artikel}

Kata Kunci :

Algoritma Apriori, Aturan

Assosiatif, Data Penjualan, Data Mining

\section{Keywords :}

Associative Rules, Apriori Algorithms, Sales Data, Data Mining

\section{Tanggal Artikel}

Dikirim : 12 November 2019

Direvisi : 14 November 2019

Diterima : 15 November 2019

\begin{abstract}
Abstrak
Permasalahan yang dihadapi oleh toko pakaian Tanjung Redjo adalah kurangnya pengelolaan terhadap data penjualan dan penataan letak produk pakaian yang tidak teratur. Penataan letak produk pakaian pada rak tidak diatur dengan baik. Kecepatan pelayanan kepada pelanggan dapat ditingkatkan dengan membuat penataan letak produk pakaian yang baik dan teratur, sehingga staf toko dapat mencari produk pakaian dengan cepat. Pembeli juga dapat mencari dan melihat perlengkapan pakaian yang sering terjual secara bersamaan dengan cepat, sehingga berpotensi meningkatkan omset penjualan toko. Penataan letak produk pakaian yang lebih baik dan teratur ini dapat dilakukan dengan menganalisis transaksi penjualan yang terjadi sehari-hari pada toko dengan menggukan algoritma Apriori. Dengan menggunakan algoritma ini, pemilik toko dapat mengetahui kecenderungan kombinasi produk pakaian yang sering terjual pada saat bersamaan, sehingga pemilik toko dapat mengatur penataan letak produk pakaian yang baik dan teratur agar pembeli atau karyawan dapat mencari dan mengambil produk pakaian dengan cepat. Cara kerja algoritma Apriori untuk menemukan kombinasi produk pakaian yang sering terjual secara bersamaan dari transaksi penjualan. Aturan yang diterapkan Jika beli KA-701 dan KK-201 dan SP-2001, maka beli ST-651. Nilai Support dan Confident dihitung sampai 4 item kombinasi diperoleh untuk mendapatkan output aturan assosiatif transaksi penjualan terlaris.
\end{abstract}

\section{Abstract}

The problem faced by the Tanjung Redjo clothing store is the lack of management of sales data and irregular arrangement of clothing products. The arrangement of the location of clothing products on the shelf is not well regulated. The speed of service to customers can be improved by making the layout of clothing products good and orderly, so that store staff can find clothing products quickly. Shoppers can also search and view apparel accessories that are often sold together quickly, potentially increasing store sales turnover. A better and more organized arrangement of clothing products can be done by analyzing sales transactions that occur daily at the store by using the Apriori algorithm. By using this algorithm, the shop owner can find out the tendency of a combination of clothing products that are often sold at the same time, so that the shop owner can arrange the layout of clothing products well and regularly so that buyers or employees can find and retrieve clothing products quickly. How the Apriori algorithm works to find a combination of clothing products that are often sold simultaneously from a sales transaction. Rules applied If buying KA-701 and KK-201 and SP-2001, then buy ST-651. Support and Confidence values are calculated until 4 combination items are obtained to get the best selling associative rule output output. 


\section{PENDAHULUAN}

Setiap hari di toko terjadi transaksi penjualan produk pakaian. Data penjualan akan terus bertambah seiring dengan bertambahnya waktu dan menyebabkan data transaksi penjualan bertambah besar. Biasanya data penjualan hanya digunakan sebagai dokumentasi (history), dan tidak diketahui manfaat dari data tersebut selanjutnya [1]. Sebenarnya terdapat informasiinformasi bermanfaat di dalam data penjualan yang dapat diekstrak dan dimanfaatkan untuk pengambilan keputusan dan untuk memperoleh informasi berharga, seperti untuk mengetahui kombinasi produk pakaian yang sering terjual secara bersamaan, sehingga pemilik toko dapat membuat promo untuk paket-paket tertentu yang dapat meningkatkan omset penjualan toko dan menyusun pakaian yang sering terjual bersamaan pada rak yang berdekatan. permasalahan yang ditemukan di dalam penelitian pemilik toko tidak mengetahui kombinasi produk pakaian yang sering terjual secara bersamaan, pemilik toko tidak dapat membuat promo harga untuk paket-paket tertentu yang melibatkan produk pakaian yang sering terjual secara bersamaan, sehingga dapat meningkatkan omset penjualan, pemilik toko tidak menyusun pakaian yang sering terjual bersamaan pada rak yang berdekatan. Algoritma data mining yang dapat digunakan untuk menganalisis transaksi penjualan adalah algoritma Apriori [2]. Algoritma Apriori termasuk jenis analisis asosiasi pada data mining. Analisis asosiasi merupakan teknik yang digunakan untuk menemukan aturan asosiatif antara suatu kombinasi barang. Contoh aturan asosiatif dari analisis transaksi penjualan adalah dapat diketahuinya berapa besar kemungkinan seorang pelanggan membeli pakaian $\mathrm{A}$ bersamaan dengan pakaian $\mathrm{B}$. Penelitian berjudul Penerapan Data Mining Dalam Pengelompokan Penderita Thalassaemia, Preprocessing Data Mining dapat meningkatkan kualitas data, data yang dianalisis yaitu data rekam medik penderita Thalassaemia. penelitian ini dapat menjadi acuan terhadap pemberian jumlah obat kepada penderita. Sehingga menjaga penderita Thalassaemia agar tidak segera dilakukan operasi pengangkatan limpa terutama pada penderita cluster 3 dengan jumlah transfusi 1 bulan 2 kali [3].

\section{METODOLOGI PENELITIAN}

\subsection{Tahapan Penelitian}

Operasi data mining dapat dibedakan menjadi dua, yaitu bersifat: (Hermawati, 2013:5) 1) Prediksi (Prediction Driven) menjelaskan prediksi untuk menjawab pertanyaan apa dan sesuatu yang bersifat remang-remang atau transparan. Operasi prediksi digunakan untuk validasi hipotesis, querying dan pelaporan, analisis multidimensi, Online Analytical Processing (OLAP), serta analisis statistic, 2) Penemuan (Discovery Driven) menjelaskan penemuan bersifat transparan dan untuk menjawab pertanyaan mengapa [4]. Operasi penemuan digunakan untuk analisis data eksplorasi, pemodelan prediktif, segmentasi database, analisis keterkaitan (link analysis) dan deteksi deviasi. Perancangan aplikasi implementasi data mining pada penjualan produk pakaian dengan algoritma Apriori menggunakan metodologi Evolutionary Prototype [5]. Metodologi ini merupakan metode yang menyajikan gambaran lengkap tentang sistem, pengguna dapat melihat pemodelan sistem dari sistem tampilan maupun teknik prosedural yang akan dibangun, Gambar 1.

\subsection{Data Mining}

Data mining adalah proses yang mempekerjakan satu atau lebih teknik pembelajaran komputer (machine learning) untuk menganalisis dan mengekstraksi pengetahuan (knowledge) secara otomatis [6]. Definisi lain di antaranya adalah pembelajaran berbasis induksi (induction based learning) adalah proses pembentukan definisi-definisi konsep umum yang dilakukan dengan cara mengobservasi contoh-contoh spesifik dari konsep-konsep yang akan dipelajari. Knowledge Discovery in Databases (KDD) adalah penerapan metode saintifik pada data mining. Dalam konteks ini, data mining merupakan satu langkah dari proses $\mathrm{KDD}[7]$. 


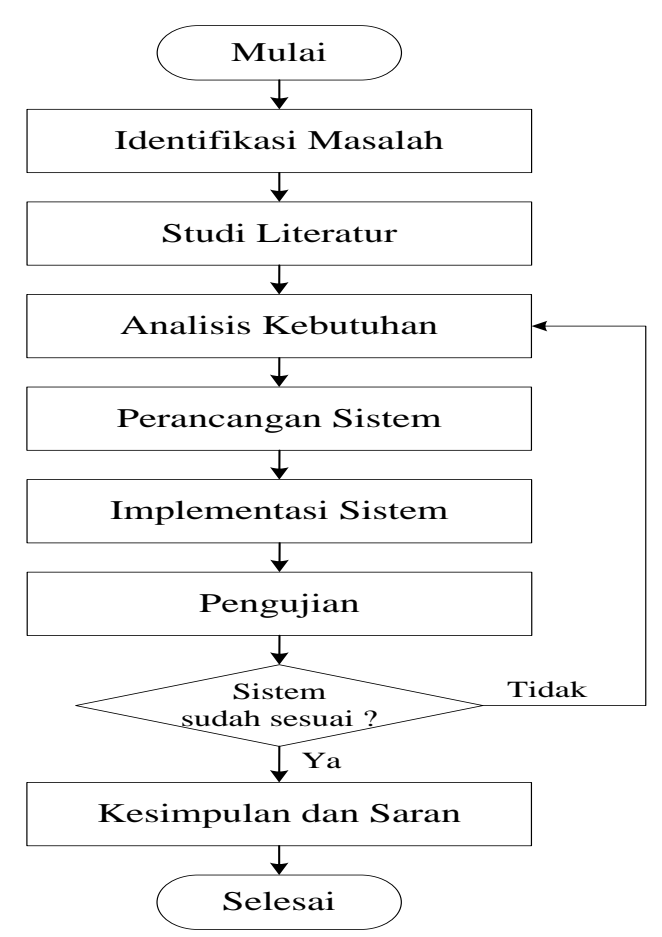

\section{Gambar 1. Tahapan Penelitian}

\subsection{Algoritma Apriori}

Metodologi dasar analisis asosiasi atau market basket analysis terbagi menjadi dua tahap, [8], [9].

1. Analisa Pola Frekuensi Tinggi

Tahap ini mencari kombinasi item yang memenuhi syarat minimum dari nilai support dalam database. Nilai support sebuah item diperoleh dengan rumus:

$$
\operatorname{Support}(A)=\frac{\text { Jumlah transaksi mengandung } A}{\text { Total Transaksi }} \times 100 \%
$$

nilai support dari 2 buah item diperoleh dari rumus berikut:

$$
\text { Support }(A \cap B)=\frac{\text { Jumlah transaksi mengandung } A \text { dan } B}{\text { Total Transaksi }} \times 100 \%
$$

2. Pembentukan Aturan Asosiasi

Setelah semua pola frekuensi tinggi ditemukan, barulah dicari aturan asosiasi dengan memenuhi syarat minimum untuk confidence dengan menghitung confidence aturan asosiatif $A \mid B$. Nilai confidence dari aturan A | B diperoleh dari rumus [10]:

$$
\text { Confidence }=\mathrm{P}(\mathrm{B} \mid \mathrm{A})=\frac{\text { Jumlah transaksi mengandung } A \text { dan } B}{\text { Jumlah transaksi mengandung } A} \times 100 \%
$$

Proses kerja algoritma apriori dapat digambarkan dalam bentuk flowchart, Gambar 2. 


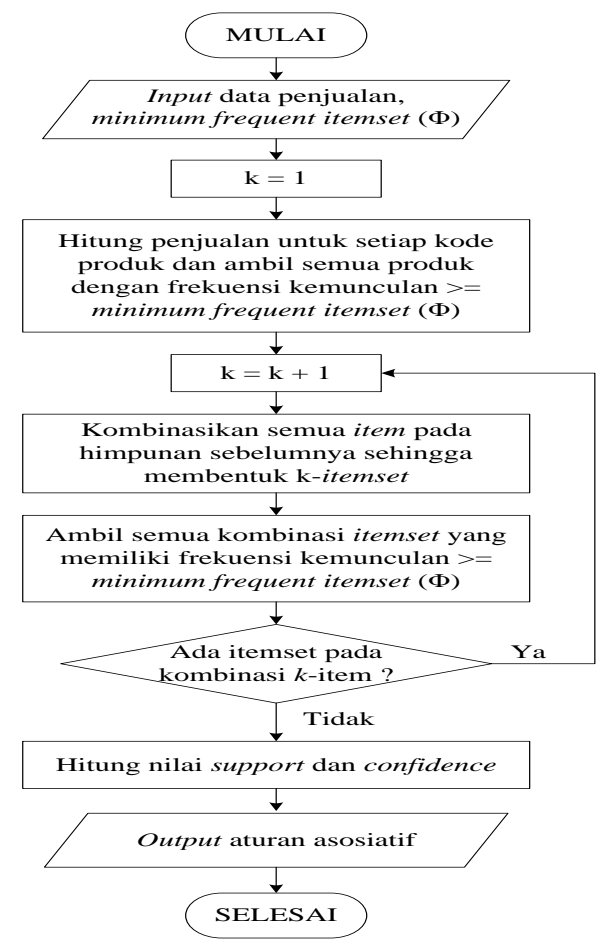

Gambar 2. Flowchart Algoritma Apriori

\section{HASIL DAN PEMBAHASAN}

Analisis kebutuhan sistem merupakan proses identifikasi dan evaluasi permasalahan yang terdapat di dalam suatu sistem, sehingga sistem yang dibangun sesuai dengan kriteria yang diharapkan. Ada dua jenis kebutuhan yang harus dianalisis, yaitu analisis kebutuhan fungsional dan analisis kebutuhan nonfungsional. Aplikasi implementasi data mining pada penjualan produk pakaian dengan Algoritma Apriori pada toko pakaian Tanjung Redjo harus memenuhi kebutuhan fungsional a) input aplikasi berupa data pakaian, yaitu kode pakaian dan nama pakaian. B) input aplikasi berupa transaksi penjualan, yaitu nomor transaksi dan tanggal transaksi serta produk pakaian yang terjual dalam suatu transaksi. c) aplikasi dapat menentukan nilai minimum support atau minimum frequent set ( $\delta$ ), dimana frequent set merupakan jumlah transaksi dari item-item yang terjual pada suatu transaksi yang dibatasi dari 2 hingga 99. d) Pengguna dapat memilih tanggal transaksi untuk membatasi periode dari transaksi yang akan dianalisis. e) aplikasi memiliki output berupa aturan asosiatif yang menyatakan kombinasi barang, nilai Support (S) dan nilai Confidence (C) dalam bentuk persentase. Data dalam penelitian terdiri dari, data pakaiai, Tabel 1 dan data penjualan, Tabel 2.

Tabel 1. Data Pakaian

\begin{tabular}{ll}
\hline Kode & Nama Produk Pakaian \\
\hline SN-501 & Sandal 501 \\
SP-2001 & Sepatu 2001 \\
KK-201 & Kaos Kaki 201 \\
KM-2101 & Kemeja 2101 \\
KA-701 & Kaos 701 \\
ST-651 & Stelan 651 \\
SP-801 & Sepatu 801 \\
TS-801 & Tas Sepatu 801 \\
RK-901 & Rok 901 \\
CL-901 & Celana 901 \\
\hline
\end{tabular}

Tabel 2. Data Penjualan

\begin{tabular}{cl}
\hline No Transaksi & \multicolumn{1}{c}{ Produk Pakaian yang Terjual } \\
\hline 001 & CL-901, KM-2101, SN-501 \\
002 & KA-701, ST-651 \\
003 & SP-2001 \\
004 & SP-801, TS-801, KK-201 \\
005 & RK-901, CL-901 \\
006 & SN-501, ST-651, TS-801 \\
007 & CL-901, RK-901 \\
008 & KK-201, ST-651, KA-701, SP-2001 \\
009 & SP-2001, KK-201 \\
010 & SP-801, SN-501 \\
011 & RK-901, KA-701, ST-651 \\
012 & ST-651, SN-501, KA-701, KK-201, SP-2001 \\
\hline
\end{tabular}


Cara kerja algoritma Apriori untuk menemukan kombinasi produk pakaian yang sering terjual secara bersamaan dari transaksi penjualan :

1.Sebagai contoh, nilai minimum frequent itemset $(\Phi)$ ditentukan $=2$, yang artinya kombinasi produk pakaian (itemset) harus muncul minimal 2 kali pada himpunan seluruh transaksi penjualan, untuk memenuhi syarat masuk ke himpunan baru berikutnya.

2.Untuk menemukan kombinasi 1-itemset atau nilai $k=1$, lakukan :

a. Hitung setiap produk pakaian yang terjual berdasarkan kode produk: $\{C L-901\}=32)\{K A-701\}=43)\{K K-201\}=$ 4 4) $\{\mathrm{KM}-2101\}=15)\{\mathrm{RK}-901\}=36)\{\mathrm{SN}-501\}=47)\{\mathrm{SP}-2001\}=4$ 8) $\{\mathrm{SP}-801\}=29)\{\mathrm{ST}-651\}=510)(\mathrm{TS}-$ $801\}=2$

b. Ambil kode produk pakaian yang memenuhi syarat, yaitu terjual minimal 2 kali (atau $\leq \Phi)$ dan masukkan ke hasil frequent itemset untuk $k=1$. Hasil himpunan $F(1)\{C L-901\}=32)\{K A-701\}=43)\{K K-201\}=44)\{R K-901\}=3$ 5) $\{\mathrm{SN}-501\}=46)\{\mathrm{SP}-2001\}=47)\{\mathrm{SP}-801\}=28)\{\mathrm{ST}-651\}=5$ 9) $\{\mathrm{TS}-801\}=2$

3.Untuk menemukan kombinasi 2-itemset atau nilai $k=2$, Kombinasikan semua item di F $\{1\}$ sehingga membentuk 2 itemset, dan hitung frekuensi penjualannya. Ambil kombinasi yang memenuhi syarat, yaitu terjual minimal 2 kali $($ atau $\leq \Phi)$ dan masukkan ke hasil frequent itemset untuk $k=2$. Hasil himpunan $F(2)$ yaitu 1) $\{C L-901, R K-901\}=2$; 2) $\{\mathrm{KA}-701, \mathrm{KK}-201\}=2 ; 3)\{\mathrm{KA}-701, \mathrm{SP}-2001\}=2 ; 4)\{\mathrm{KA}-701, \mathrm{ST}-651\}=4 ; 5)\{\mathrm{KK}-201, \mathrm{SP}-2001\}=3 ; 6)$ (KK$201, \mathrm{ST}-651\}=2 ; 7)\{\mathrm{SN}-501, \mathrm{ST}-651\}=2 ; 8)\{\mathrm{SP}-2001, \mathrm{ST}-651\}=2$

4. Untuk menemukan kombinasi 3-itemset atau nilai $k=3$,:

Kombinasikan semua item di $F\{2\}$ sehingga membentuk 3 itemset, dan hitung frekuensi penjualannya. Itemsetyang dapat digabungkan adalah itemset-itemsetyang memiliki kesamaan dalam k-1 item pertama. Misalnya, \{KA-701, KK201\} dan $\{K A-701, S P-2001\}$ memiliki itemset pertama ( $\mathrm{k}-1$ atau 2-1 $=1$ ) yang sama, yaitu KA-701, maka dapat digabungkan menjadi 3-itemset baru, yaitu $\{K A-701, K K-201$, SP-2001\}. $\{K A-701, K K-201, S P-2001\}=2 ; 2)\{K A-701$, KK-201, ST-651 $\}=2$; 3) $\{$ KA-701, SP-2001, ST-651 $\}=2$; 4) $\{$ KK-201, SP-2001, ST-651 $=2$. Ambil kombinasi yang memenuhi syarat, yaitu terjual minimal 2 kali $($ atau $\leq \Phi)$ dan masukkan ke hasil frequent itemset untuk $k=2$. Hasil himpunan $\mathrm{F}(3)$

1) $\{K A-701, K K-201, S P-2001\}=22$ 2) $\{K A-701, K K-201, S T-651\}=2 ; 3)\{K A-701, S P-2001, S T-651\}=24)\{K K-201$, SP-2001, ST-651\} $=2$

5. Kombinasi dari $F(3)$ dapat digabungkan menjadi calon itemset $F(4)$, dengan syarat memiliki kesamaan dalam ( $\mathrm{k}$ 1) item pertama. Hasil penggabungannya yaitu $\{K A-701, K K-201, S P-2001, S T-651\}=2 F(4)$ atau frequent item set utk $\mathrm{k}=4$ yang memiliki frekuensi penjualan lebih besar atau sama dengan 2 adalah: $\{K A-701, K K-201$, SP-2001, ST$651\}=2$.

6. F\{4\} hanya berisi 1 itemset, sehingga tidak dapat dikombinasikan dengan itemset lainnya untuk menghasilkan kombinasi 5-itemsett. Dengan demikian, algoritma Apriori berhenti karena tidak ada kombinasi 5-itemsetyang dapat dihasilkan.

7. Hasilkan aturan asosiatif dengan menggunakan rule if $x$ then $y$, dimana $x$ adalah antecendent dan $y$ adalah consequent. Berdasarkan rule tersebut, maka dibutuhkan 2 buah item, dimana salah satunya sebagai antecedent dan sisanya sebagai consequent. Dari langkah sebelumnya didapat 4 buah himpunan yaitu $F(2), F(3), F(4)$ dan $F(5)$. $F(1)$ tidak disertakan karena hanya terdiri dari 1 item.

8. Untuk antecedentboleh lebih dari 1 unsur, sedangkan untuk consequent hanya terdiri dari 1 unsur. Hasilkan aturan asosiatif untuk 2-itemset dan hitung support dan confidence $\mathrm{F}(2)=(\{\mathrm{CL}-901, \mathrm{RK}-901\},\{\mathrm{KA}-701, \mathrm{KK}-201\},\{\mathrm{KA}-701$, SP-2001\}, \{KA-701, ST-651\}, \{KK-201, SP-2001\}, \{KK-201, ST-651\}, \{SN-501, ST-651\}, \{SP-2001, ST-651\})

Misalkan, aturan "Jika membeli CL-901, maka membeli RK-901". Untuk jumlah CL-901 dan RK-901 yang dibeli sekaligus, terdapat 2 transaksi. Jumlah seluruh transaksi penjualan adalah 12 transaksi, sehingga support-nya:

SUPPORT $=\frac{2}{12} \times 100 \%=16.67 \%$

Untuk jumlah CL-901 dan RK-901 yang dibeli sekaligus, terdapat 2 transaksi. Jumlah transaksi yang membeli CL-

901 adalah 3 transaksi, sehingga confidence-nya

$$
\text { CONFIDENCE }=\frac{2}{3} \times 100 \%=66.67 \%
$$

9. Hasilkan aturan asosiatif untuk 3-itemset dan hitung support dan confidence dengan cara yang sama. Aturan untuk 3 itemset, diurutkan berdasarkan nilai $S \times C$ tertinggi

10. Hasilkan aturan asosiatif untuk 4-itemset dan hitung support dan confidence dengan cara yang sama. Aturan untuk 4 itemset, diurutkan berdasarkan nilai $S \times C$ tertinggi 
Activity Diagram dari Sistem menampilkan alur sistem yang dimulai dari user melakukan input data produk pakaian dan transaksi penjualan, kemudian sistem menyimpan data produk pakaian dan transaksi penjualan di dalam database. Kemudian user memilih proses data mining, dan sistem mengambil semua transaksi penjualan di database, melakukan proses analisis dengan algoritma Apriori dan menghasilkan output berupa aturan asosiatif, Gambar 3

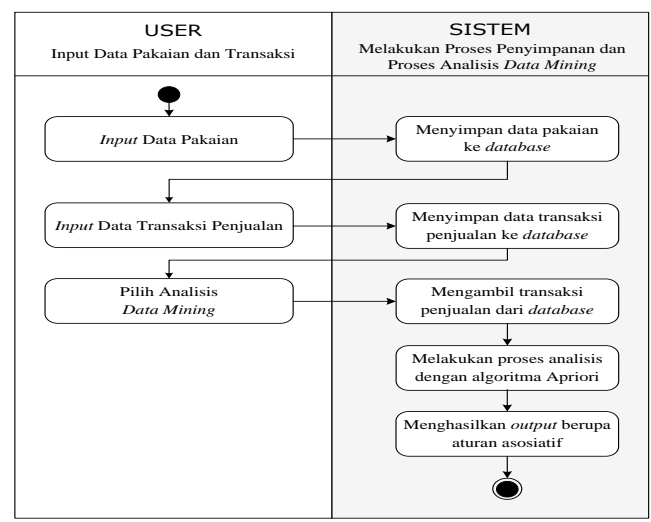

Gambar 3. Activity Diagram

Hasil implementasi dari aplikasi data mining pada penjualan produk pakaian dengan algoritma Apriori: 1. Saat aplikasi dijalankan, form Utama akan muncul saat aplikasi dijalankan, gambar 4.

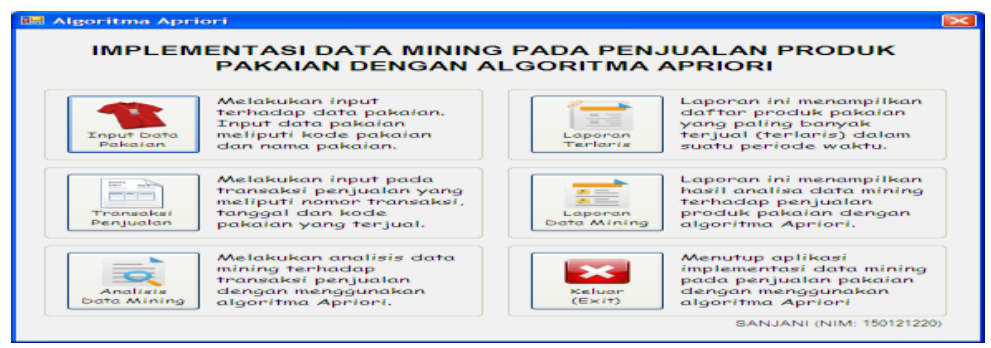

Gambar 4. Tampilan Menu Utama

2. Untuk membuka Form Pakaian, pengguna dapat menekan tombol Input Data Pakaian pada form Utama. Form ini berfungsi untuk memasukkan kode dan nama produk pakaian yang digunakan pada transaksi penjualan. Form Transaksi Penjualan, pengguna dapat menekan tombol berfungsi untuk memasukkan transaksi penjualan yang akan dilakukan analisis data mining, dapat dilihat pada Gambar 5.
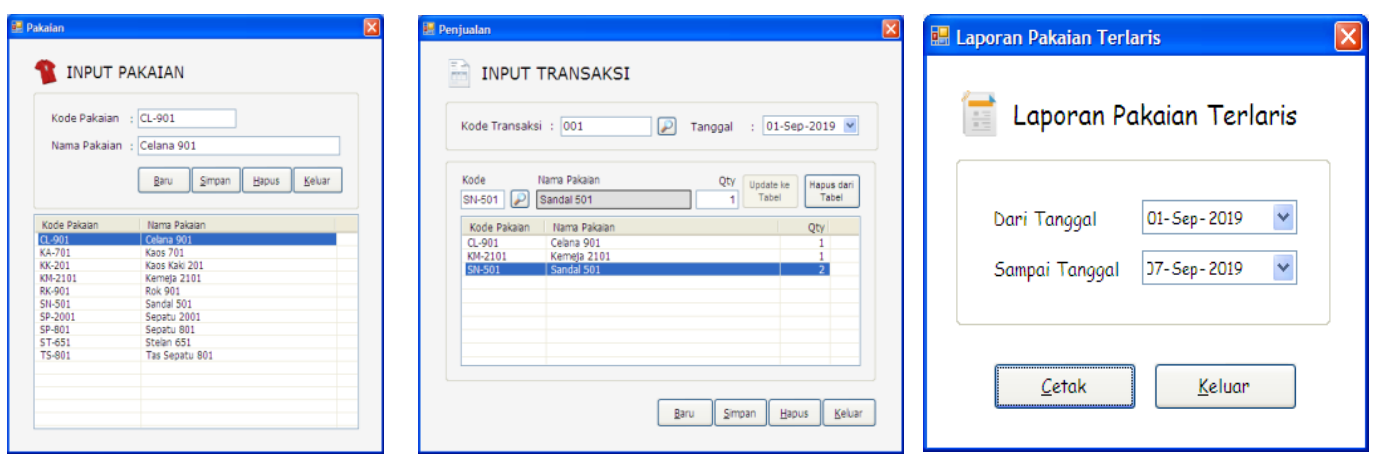

Gambar 5. Tampilan Form Data Mining

Form Analisis Data Mining berfungsi untuk menampilkan hasil analisis data mining dari input transaksi penjualan dengan algoritma Apriori. Aturan asosiatif yang merupakan hasil dari algoritma Apriori ditampilkan pada form Analisis, dapat dilihat pada Gambar 6. 

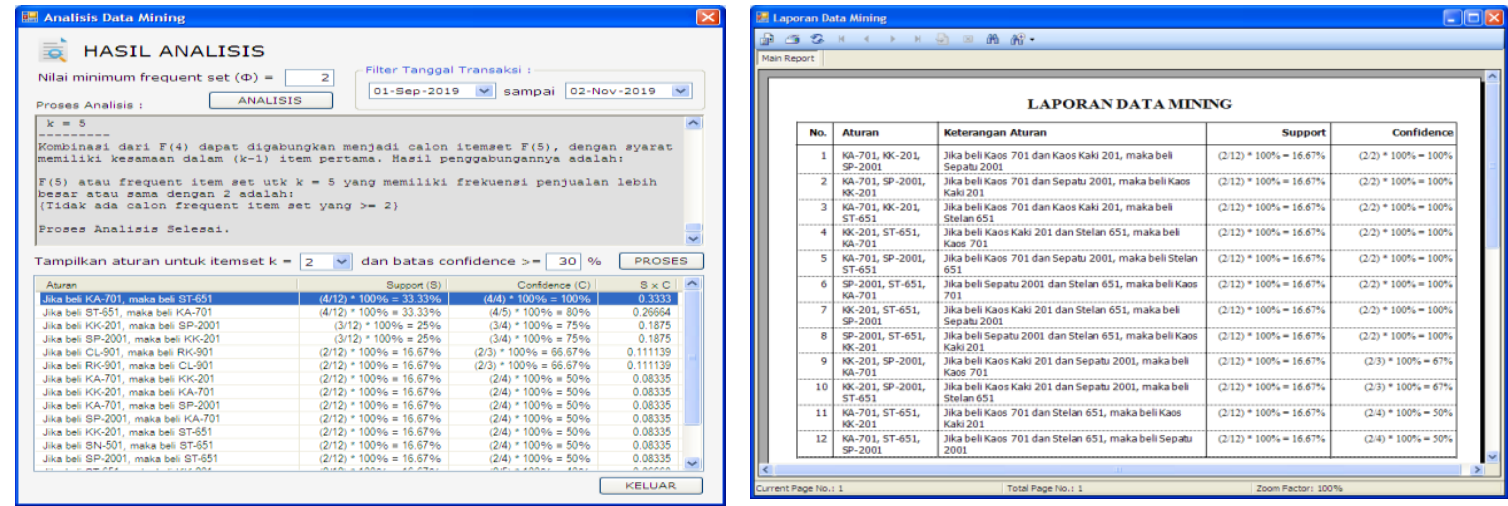

\section{KESIMPULAN}

Gambar 6. Form Laporan Data Mining

Hasil penelitian menyatakan bahwa aturan asosiatif yang dihasilkan oleh aplikasi dapat digunakan oleh pemilik toko untuk membuat promo harga paket-paket tertentu yang melibatkan produk pakaian yang sering terjual secara bersamaan, sehingga dapat meningkatkan omset penjualan, dan pemilik toko dapat menyusun pakaian yang sering terjual bersamaan pada rak yang berdekatan. Aplikasi dapat menghasilkan aturan asosiatif, nilai support dan confidence dengan menggunakan algoritma Apriori yang menyatakan kombinasi produk pakaian yang sering terjual secara bersamaan. Aplikasi dapat menampilkan tahapan analisis algoritma Apriori, sehingga dapat membantu pembelajaran terhadap cara kerja algoritma Apriori.

\section{DAFTAR PUSTAKA}

[1] Dwi, 0. \& Hajjah, A. 2019. Perancangan Sistem Penjadwalan Seminar Proposal Dan Sidang Skripsi Dengan Metode Algoritma Genetika. JOISIE Journal Of Information System And Informatics Engineering. Vol. 3, No.1. HIm 32-40.

[2] Mulyana, H. 2014. Pemakaian Metode Asosiasi Dalam Data Mining Untuk Penjualan Lebih Dari Satu Jenis Produk Pada Perusahaan, Jurnal Pilar Nusa Mandiri, Vol.X No.1, hal 47-56.

[3] Sikumbang, E. D. 2018. Penerapan Data Mining Penjualan Sepatu Menggunakan Metode Algoritma Apriori. Jurnal Teknik Komputer Vol 4, No. 1.

[4] Fajrin, A. A. \& Maulana A. 2018. Penerapan Data Mining Untuk Analisis Pola Pembelian Konsumen Dengan Algoritma Growth Pada Data Transaksi Penjualan Spare Part Motor. Kumpulan jurnaL IImu Komputer (KLIK). Volume 05 , No.01.

[5] Sinaga, A. S. 2019. Implementasi OLAP Menggunakan Dashboard Holistics Software Pada LPPM STMIK Pelita Nusantara, Jutikomp, Volume 2 Nomor 1. hal : 55-59.

[6] Sinaga, A. S. RM. 2017. Data Mining Informasi Tingkat Kelulusan Mahasiswa STMIK Pelita Nusantara, Jurnal Manajemen dan Informatika Komputer Pelita Nusantara, hal 27-35.

[7] Sulastri, H. \& Gufroni, A. I. 2017. Penerapan Data Mining Dalam Pengelompokan Penderita Thalassaemia. Jurnal Nasional Teknologi dan Sistem Informasi

[8] Syahdan, S. A \& Sindar, A. 2018. Data Mining Penjualan Produk Dengan Metode Apriori Pada Indomaret Galang Kota, Jurnal Nasional Komputasi dan Teknologi Informasi, Vol. 1 No. 2. hal: 56-63.

[9] Tamba, S. P. \& Kesuma, FT 2019,. Penerapan Data Mining Untuk Menentukan Penjualan Sparepart Toyota Dengan Metode K-Means Clustering, Jurnal Sistem Informasi IImu Komputer Prima (JUSIKOM PRIMA), Vol. 2 No. 2, hal: 67-72.

[10] Amalia, H., \& Evicienna, E. (2017). Komparasi Metode Data Mining Untuk Penentuan Proses Persalinan Ibu Melahirkan. Jurnal Sistem Informasi, 13(2), 103-109. 